\title{
The effects of Pennyroyal (Mentha pulegium L.) on performance, carcass and meat quality in Japanese quails (Coturnix coturnix japonica)
}

\author{
Mükremin ÖLMEZ ${ }^{1, a \bowtie}$, Serpil ADIGÜZEL IŞIK ${ }^{2, b}$, Tarkan ŞAHİN ${ }^{1, c}$, Mehmet Akif YÖRÜK $^{3, d}$ \\ ${ }^{1}$ Department of Animal Nutrition and Nutritional Diseases, Faculty of Veterinary Medicine, Kafkas University, Kars; ${ }^{2}$ Department of \\ Animal Breeding and Husbandry, Faculty of Veterinary Medicine, Kafkas University, Kars; ${ }^{3}$ Department of Animal Nutrition and \\ Nutritional Diseases Faculty of Veterinary Medicine, Atatürk University, Erzurum, Turkey. \\ aORCID: 0000-0002-5003-3383; ' $\mathrm{ORCID:} \mathrm{0000-0002-4456-8779;} \mathrm{'} \mathrm{ORCID:} \mathrm{0000-0003-0155-2707;}$ \\ ${ }^{\mathrm{d}}$ ORCID: 0000-0002-5833-9803.
}

Corresponding author: mukremin.olmez@hotmail.com

Received date: 17.07.2020 - Accepted date: 26.11.2020

\begin{abstract}
This study investigated the Pennyroyal in terms of its effects on performance and meat quality (color and $\mathrm{pH}$ ) in Japanese quails in different levels. A total of one day-old Japanese quail chicks were randomly distributed to a control and two experimental groups containing three different levels of pennyroyal (0.0, 0.1 and $0.2 \%)$. Each experimental group was divided into five repetitive groups with, ten quail chicks in each group. At the end of the experiment, the performance values and meat quality parameters (color and $\mathrm{pH}$ ) were measured. Significant differences were found between the groups according to the growth performance of the quails $(\mathrm{P}<0.05)$. At the end of the study, the body weight and body weight gain of the experimental groups in which $0.1 \%$ (P1) and $0.2 \%(\mathrm{P} 2)$ pennyroyal supplemented were found to be higher than the control group. It was observed that the feed consumption increased in the $\mathrm{P} 2$ group compared to the control group, and the feed conversion rate decreased $(\mathrm{P}<0.05)$. There was no significant difference was observed in the carcass yield, heart, liver and gizzard weight $(\mathrm{P}>0.05)$. The brightness $\left(\mathrm{L}^{*}\right)$, redness $\left(\mathrm{a}^{*}\right)$, yellowness $\left(b^{*}\right)$ and $\mathrm{pH}$ values of the breast meat were not affected by the supplementation of pennyroyal $(\mathrm{P}>0.05)$. According to the results of the study, the supplemented of pennyroyal by $0.2 \%$ was more effective on the performance.
\end{abstract}

Keywords: Meat color, pennyroyal, performance, $\mathrm{pH}$, quail.

\section{Yarpuzun (Mentha pulegium L.) Japon bıldırconlarında (Coturnix coturnix japonica) performans, karkas ve et kalitesi üzerine etkisi}

Özet: Bu çalışmada, Yarpuzun (Mentha pulegium L.) farklı seviyelerde Japon bıldırcınlarında performans ve et kalitesi (renk ve $\mathrm{pH})$ üzerine etkisi araştırılmıştır. Toplam 150 adet günlük yaşta Japon bıldırcın civcivi üç farklı düzeyde yarpuz içeren ( $\% 0,0,0,1$ ve $0,2)$ bir kontrol ve iki deneme grubuna rastgele dağıtıldı. Her deneme grubu içerisinde 10 bıldırcın bulunan beş tekerrürlü gruba ayrıldı. Deneme sonunda performans değerleri ve et kalite parametreleri (renk ve $\mathrm{pH}$ ) ölçüldü. Bıldırcınların büyüme performansı değerlendirildiğinde gruplar arasında önemli farklılıklar bulundu $(\mathrm{P}<0,05)$. Çalışma sonu itibariyle \%0,1 (P1) ve \%0,2 (P2) yarpuz ilave edilen deneme gruplarının canlı ağırlık ve canlı ağırlık artışları kontrol grubuna oranla yüksek bulundu. Yem tüketiminin P2 grubunda kontrol grubuna oranla arttığı, yemden yararlanma oranının ise düştüğü gözlendi $(\mathrm{P}<0,05)$. Karkas randımanı, kalp, karaciğer ve taşlık ağırlıkları açısından anlamlı bir fark olmadığı görüldü $(\mathrm{P}>0,05)$. Göğüs etinin parlaklık ( $\left.\mathrm{L}^{*}\right)$, kırmızılık $\left(\mathrm{a}^{*}\right)$ ve sarılık ( $\left.\mathrm{b}^{*}\right)$ ile $\mathrm{pH}$ değerleri yarpuz ilavesinden etkilenmedi $(\mathrm{P}>0,05)$. Çalışma sonuçlarına göre yarpuzun $\% 0,2$ düzeyinde ilavesinin performans üzerine daha etkili olduğu belirlendi.

Anahtar sözcükler: Bıldırcın, et rengi, performans, $\mathrm{pH}$, yarpuz.

\section{Introduction}

Mentha pulegium L, which belongs to the Mentha species of the Labiatae family, is ubiquitous in Europe, North Africa and Central Asia and known as pennyroyal (11). It has been used as flavorant, expectorant, appetite regulator or diuretic for many years. In addition, it is widely used in the treatment of diseases such as feed poisoning, bronchitis and tuberculosis (21). In addition to these effects, it has also been reported to have aromatic regulation, antioxidant, anti-inflammatory and 
antimicrobial effects due to the phenolic compounds in its structure, such as Linalool, Menthone, p-Menthan, Pulegone, Piperitenone oxide $(20,35,36)$. After the prohibition of antibiotics in the breeding of poultry, pennyroyal and aromatic plants are reported to be useful due to its effects on increasing digestibility, balancing the intestinal microbial ecosystem and excreting endogenous digestive enzymes $(13,17,40)$. There is a growing awareness in consumers with the development of technology in the field of feed safety, which led to a growing interest in the use of medical aromatic plants that are not harmful to human and animal health as well as their various forms $(18,22,32)$. In many studies, it was found that pennyroyal and other Mentha species make positive contributions to the efficiency and shelf life of animal products $(5,16,26)$.

The main aim of this study was to investigate the Pennyroyal (Mentha pulegium L.) in different levels supplemented to quail rations in terms of its effects on growth performance and breast meat quality (color and $\mathrm{pH})$.

\section{Materials and Methods}

Animals, experimental design and feed: The experiment was carried out in the Kafkas University Research and Practice Farm. This study was approved by the Kafkas University Animal Experiments Local Ethics Committee (KAÜ-HADYEK/2020-008). A total of $150 \mathrm{a}$ day old Japanese quails (Coturnix coturnix japonica) were used as the animal material. The study was performed with one control and two experiment groups, each of which included 50 quail chicks. All groups were divided into five subgroups, each containing 10 quail chicks. Dried and powdered pennyroyal was added to the basic ration of the control and experimental groups by $0.0 \%$, (control) $0.1 \%$ (P1) and $0.2 \%(\mathrm{P} 2)$, respectively. The quail chicks were placed in plastic cages of $60 \times 20 \times 100 \mathrm{~cm}$. The study was completed in a total of 35 days, including 7 days of adaptation and 28 days of feeding periods. The animals were given feed and water ad libitum. Throughout the study, all animals were kept at $32-33^{\circ} \mathrm{C}$ for the first three days, which was then fixed to $25^{\circ} \mathrm{C}$ by a gradual decrease of $1-2^{\circ} \mathrm{C}$ on a weekly. The cages were kept illuminated for 24 hours/day for 35 days. The rations were prepared in accordance with the NRC (14), and chemical analyses were carried out in accordance with the AOAC (25) (Table 1).

Feed additive: Plants (pennyroyal) were collected from Kars province $\left(40^{\circ} 48^{\prime} 21.2\right.$ "N $\left.42^{\circ} 53^{\prime} 37.8^{\prime \prime} \mathrm{E}\right)$ in Turkey and harvested in its season. Plants' leaves were dried at room temperature without direct exposure to the sun light. After drying, they were powdered for supplementation to the ration. The essential oil was obtained from Pennyroyal through vapor distillation method. The main active compositions of the pennyroyal leaves essential oil were determined by GC/MS and contained $13.61 \%$ of Linalool, $10.56 \%$ of p-Menthone, $6.19 \%$ of p-Menthan, $4.45 \%$ of Pulegone, $0.11 \%$ of Isopulegone, $3.07 \%$ of Piperitenone oxide, and 0.49 of Thymol phenolic compounds (35).

Table 1. Ingredients and nutrient composition of diet.

\begin{tabular}{ll}
\hline Ingredients & $\mathbf{\%}$ \\
\hline Corn, yellow & 46.30 \\
Soybean meal $(48 \% \mathrm{CP})$ & 32.41 \\
Barley meal & 11.00 \\
Corn gluten meal & 4.40 \\
Wheat bran & 2.12 \\
Vegetable oil & 0.60 \\
Limestone & 1.80 \\
Dicalcium phosphate & 1.12 \\
Salt & 0.30 \\
DL-methionine & 0.10 \\
L-lysine sulfate & 0.40 \\
Vit-min mix ${ }^{1}$ & 0.25 \\
\hline Analyzed values & \\
\hline CP $(\%)$ & 24.00 \\
ME $(\mathrm{kcal} / \mathrm{kg})$ & 2901 \\
Ca $(\%)$ & 0.80 \\
Av. P $(\%)$ & 0.38 \\
\hline CP: Crro & Ca: Calcium, Av.
\end{tabular}

CP: Crude protein, ME: Metabolism energy, Ca: Calcium, Av. P: Available phosphorus

${ }^{1}$ Vit-min mix: Vit A; $15.00 \mathrm{IU} / \mathrm{kg}$, Vit D; $3.30 \mathrm{IU} / \mathrm{kg}$, Vit E; $25.00 \mathrm{IU} / \mathrm{kg}, \mathrm{K} ; 0.86 \%, \mathrm{Mg} ; 0.16 \%$, S; $0.21 \%, \mathrm{Fe} ; 146.89 \mathrm{mg} / \mathrm{kg}$, $\mathrm{Mn} ; 121.11 \mathrm{mg} / \mathrm{kg}, \mathrm{I} ; 0.50 \mathrm{mg} / \mathrm{kg}, \mathrm{Zn} ; 110.03 \mathrm{mg} / \mathrm{kg}, \mathrm{Cu} ; 13.05$ $\mathrm{mg} / \mathrm{kg}$.

Performance: Body weight (BW) and feed consumption (FC) were determined in all groups every week. The increase in body weight gain (BWG) and feed conversion rate $(\mathrm{FCR})$ were calculated $(\mathrm{FC} / \mathrm{BWG})$ based on the differences obtained as a result of the weighing processes. At the end of the study, 10 quails were randomly selected from each group to analyze their carcass traits. The animals were not fed for 12 hours. Then, they were weighed individually and slaughtered after determining their slaughtering weight. The blood of the slaughtered animals was drained, and their plume was plucked. Subsequently, internal organs (heart, liver and gizzard) were removed to calculate the carcass and internal organ weights.

Determining the color quality and $\mathrm{pH}$ of meat: Breast meat samples were taken from the slaughtered animals to determine the color intensity and $\mathrm{pH}$. A colorimeter (Minolta-Japan) was used to determine the color intensities of the breast meat samples ( $\mathrm{L}^{*}$ : brightness, $\mathrm{a}^{*}$ : redness, $\mathrm{b}^{*}$ : yellowness). The color intensities were determined as per the characteristics specified by the International Commission on Illumination. Average values were determined through the 
measurements performed at four different parts of each sample. In order to determine the $\mathrm{pH}$ values of the breast meat samples, 10 grams of breast meat was added to 100 $\mathrm{ml}$ of purified water. Then it was homogenized and measured using a pH meter (SCHOTT L 6880).

Statistical analysis: The performance and the parameters of breast meat quality (color, $\mathrm{pH}$ ) were evaluated on the SPSS 20.0 (IBM-USA) statistics software. The difference between the results of the groups was analyzed with one-way variance analysis (ANOVA). The Duncan, multiple comparison test, was used in the bilateral comparisons between the groups. The level of significance was determined to be at $\mathrm{P}<0.05$.

\section{Results}

It was observed that pennyroyal had positive effects on performance in the quails $(\mathrm{P}<0.05)$. While the $\mathrm{BW}$, BWG and FC values in the groups with pennyroyal supplementations tended to increase compared to the control group, the FCR had a significant decrease in the group with the supplementation of pennyroyal by $0.2 \%$ (Table 2). It was determined that pennyroyal did not have any effects on the post-slaughtering carcass yield and weights of the internal organs $(\mathrm{P}<0.05)$ (Table 3$)$.

It was observed that pennyroyal did not have any statistical effects on the color of the breast meat $\left(\mathrm{L}^{*}, \mathrm{a}^{*}\right.$, $\left.\mathrm{b}^{*}\right)$ and $\mathrm{pH}$ value $(\mathrm{P}>0.05)$ (Table 4$)$.

Table 2. The effect of Pennyroyal (M. pulegium L.) on performance parameters.

\begin{tabular}{|c|c|c|c|c|c|}
\hline \multicolumn{6}{|c|}{ BW (g) } \\
\hline & \multicolumn{3}{|c|}{ Groups } & \multicolumn{2}{|c|}{$P$ values } \\
\hline & Control & $\mathrm{P} 1$ & $\mathrm{P} 2$ & $L$ & $Q$ \\
\hline d 7 & $29.20 \pm 0.73$ & $29.00 \pm 0.17$ & $28.98 \pm 1.39$ & 0.982 & 0.939 \\
\hline d 21 & $116.05 \pm 0.59$ & $117.70 \pm 1.46$ & $118.70 \pm 1.69$ & 0.185 & 0.848 \\
\hline d 35 & $180.81 \pm 1.97^{\mathrm{b}}$ & $186.05 \pm 1.45^{\mathrm{a}}$ & $188.88 \pm 1.18^{\mathrm{a}}$ & 0.003 & 0.542 \\
\hline \multicolumn{6}{|c|}{ BWG (g/quails) } \\
\hline & \multicolumn{3}{|c|}{ Groups } & \multicolumn{2}{|c|}{$P$ values } \\
\hline & Control & $\mathrm{P} 1$ & $\mathrm{P} 2$ & $\mathrm{~L}$ & $\mathrm{Q}$ \\
\hline d 7 to 21 & $86.85 \pm 1.01$ & $88.69 \pm 1.40$ & $89.73 \pm 2.00$ & 0.207 & 0.832 \\
\hline d 21 to 35 & $64.76 \pm 1.84^{\mathrm{b}}$ & $68.36 \pm 1.07^{\mathrm{ab}}$ & $70.17 \pm 0.91^{\mathrm{a}}$ & 0.014 & 0.598 \\
\hline d 7 to 35 & $151.61 \pm 1.45^{\mathrm{b}}$ & $157.05 \pm 1.35^{\mathrm{a}}$ & $159.90 \pm 1.78^{a}$ & 0.003 & 0.506 \\
\hline \multicolumn{6}{|c|}{ FC (g) } \\
\hline & \multicolumn{3}{|c|}{ Groups } & \multicolumn{2}{|c|}{$P$ values } \\
\hline & Control & $\mathrm{P} 1$ & P2 & $\mathrm{L}$ & Q \\
\hline d 7 to 21 & $276.96 \pm 3.23$ & $279.23 \pm 4.50$ & $282.94 \pm 3.45$ & 0.272 & 0.877 \\
\hline d 21 to 35 & $259.03 \pm 4.46$ & $265.00 \pm 3.00$ & $268.35 \pm 2.45$ & 0.064 & 0.756 \\
\hline d 7 to 35 & $535.99 \pm 3.87^{\mathrm{b}}$ & $544.23 \pm 3.64^{\mathrm{ab}}$ & $551.29 \pm 3.26^{\mathrm{a}}$ & 0.004 & 0.895 \\
\hline \multicolumn{6}{|c|}{ FCR $(g / g)$} \\
\hline & \multicolumn{3}{|c|}{ Groups } & \multicolumn{2}{|c|}{$P$ values } \\
\hline & Control & $\mathrm{P} 1$ & $\mathrm{P} 2$ & $\mathrm{~L}$ & Q \\
\hline d 7 to 21 & $3.19 \pm 0.03$ & $3.15 \pm 0.05$ & $3.15 \pm 0.02$ & 0.461 & 0.572 \\
\hline d 21 to 35 & $4.00 \pm 0.04^{\mathrm{a}}$ & $3.88 \pm 0.06^{\mathrm{ab}}$ & $3.82 \pm 0.03^{\mathrm{b}}$ & 0.008 & 0.540 \\
\hline d 7 to 35 & $3.53 \pm 0.01^{\mathrm{a}}$ & $3.47 \pm 0.02^{\mathrm{ab}}$ & $3.45 \pm 0.01^{\mathrm{b}}$ & 0.001 & 0.172 \\
\hline
\end{tabular}

P1: 0.1\% Pennyroyal, P2: 0.2\% Pennyroyal, BW: Body weight, BWG: Body weight gain, FC: Feed consumption, FCR: Feed conversion rate, $L$ : Linear, $Q:$ Quadratic

a,b Values within a column with different superscripts differ significantly at $\mathrm{P}<0.05$.

Table 3. The effect of Pennyroyal (M. pulegium L.) on carcass parameters.

\begin{tabular}{lccccc}
\hline & \multicolumn{3}{c}{ Groups } & \multicolumn{2}{c}{ P values } \\
\cline { 2 - 6 } & Control & P1 & P2 & $L$ & 0.730 \\
\hline Carcass yield (\%) & $73.16 \pm 0.19$ & $73.31 \pm 0.11$ & $73.34 \pm 0.12$ & 0.380 & 0.124 \\
Heart (g) & $1.60 \pm 0.03$ & $1.61 \pm 0.06$ & $1.47 \pm 0.06$ & 0.839 & 0.542 \\
Liver (g) & $3.31 \pm 0.43$ & $2.65 \pm 0.19$ & $3.41 \pm 0.41$ & 0.130 & 0.639 \\
Gizzard (g) & $2.62 \pm 0.20$ & $2.26 \pm 0.18$ & $2.70 \pm 0.13$ & 0.738 & \\
\hline Pl: &
\end{tabular}

P1: 0.1\% Pennyroyal, P2: 0.2\% Pennyroyal, $L$ : Linear, $Q$ : Quadratic. 
Table 4. The effect of Pennyroyal (M. pulegium L.) on meat color and $\mathrm{pH}$.

\begin{tabular}{lccccc}
\hline & \multicolumn{3}{c}{ Groups } & \multicolumn{2}{c}{ P values } \\
\cline { 2 - 6 } & Control & P1 & P2 & $L$ & 0.845 \\
\hline $\mathrm{L}^{*}$ & $45.51 \pm 1.23$ & $45.96 \pm 1.79$ & $45.29 \pm 1.35$ & 0.947 & 0.694 \\
$\mathrm{a}^{*}$ & $11.60 \pm 0.44$ & $11.23 \pm 0.41$ & $11.41 \pm 0.17$ & 0.807 & 0.911 \\
$\mathrm{~b}^{*}$ & $4.85 \pm 0.19$ & $4.75 \pm 0.14$ & $4.72 \pm 0.17$ & 0.725 & 0.875 \\
$\mathrm{pH}$ & $5.48 \pm 0.07$ & $5.50 \pm 0.03$ & $5.50 \pm 0.03$ & 0.892 & \\
\hline
\end{tabular}

P1: 0.1\% Pennyroyal, P2: 0.2\% Pennyroyal, L *: Brightness, a *: Redness, b *: Yellowness, L: Linear, $Q$ : Quadratic.

\section{Discussion and Conclusion}

The supplementation of pennyroyal on quail rations had a positive effect on performance. In the study, it was determined that the supplementation of pennyroyal in increasing levels had a positive effect on the BW, BWG and FC values, compared to the control group. It was determined that the best FCR was obtained in the group (2.86) with supplementation of $0.2 \%$ of pennyroyal. The BW and BWG results obtained were in accordance with the results of the study, in which pennyroyal was used as a supporting growth agent $(33,35)$. The results of the current study also had similarities with the studies on the effects of different Mentha species (M. Longifolia and $M$. Piperita) on BW and BWG in the poultry $(3,4)$. In the broiler study, in which the pennyroyal, essential oil, probiotics and antibiotics were used in different levels, the best performance values were obtained in the group with the addition of pennyroyal, thereby affecting the BWG and FCR significantly. The results of the study suggested that pennyroyal could be used as an alternative to antibiotics in poultry (2). It is believed that the phenolic compounds in pennyroyal and other Mentha species decreased the presence of pathogenic microorganisms in the intestines of the poultry, thereby showing an antimicrobial effect as well as affecting the growth performance $(21,30)$. The fact that pennyroyal increases feed consumption due to its appetizing effect has been mentioned in the literature (21). Similarly, there have been studies, in which the Mentha species increased feed consumption $(3,4)$.

Contrary to these studies, there have been studies reporting that the Mentha species do not affect the performance values (BW, BWG and FC) in the poultry $(15,19,34)$. Erhan et al. (17) found that pennyroyal did not affect the body weight increase in broiler chickens, and it decreased the feed consumption, thereby improving the feed conversion rate. Ghalamkari et al. (20) stated that the addition of antibiotics and pennyroyal did not cause a difference in terms of the performance values of the broiler chickens, Arjomandi et al. (8) found that the pennyroyal mixed with probiotics decreased the feed consumption in laying hens, and Aydin and Bolukbasi (10) reported that the addition of pennyroyal in increasing levels $(32.5,65$ and $130 \mathrm{mg} / \mathrm{kg})$ did not affect the feed consumption in laying hens, which were not in compliance. It is believed that these differences might have stemmed from the region where the plant was grown, the harvest season, the breed of animal used, the dosage used and feeding conditions.

It was determined that the addition of pennyroyal did not affect the weights of carcass and internal organs (heart, liver and gizzard) in quails. The results of the present study were following the results of some other studies (1, 21, 31). Similarly, Nobakht et al. (33) reported that pennyroyal did not have any effects on the carcass yield or the weights of the internal organs. On the contrary, Shamlo et al. (39) stated that the pennyroyal extract $(0.50$, 100 and $150 \mathrm{ppm}$ ) increased the carcass weight, carcass yield and the weight of the heart; however, it did not have any effects on the weights of the liver and gizzard. Along with this study, there are other studies in the literature stating that the carcass parameters and internal organ weights changed due to the addition of pennyroyal and aromatic plants together or separately $(4,9,38)$. It was stated that pennyroyal increased digestive enzymes in the poultry, which had a positive effect on the pancreas, and could positively affect the carcass parameters particularly by the increase of the amino-acid absorption (6). The differences observed between studies might have resulted from the diversity of aromatic plant used, the interactions between additives, dosage, and differences in animals.

The unique color of the product is another significant criterion for consumers to choose any product. This color should not change during the time it remains on the shelf. The oxidation of the myoglobin and hemoglobin pigments is useful in the changing of the natural color of the meat (23). In the study, no pennyroyal-related effects were observed on the color intensities $\left(\mathrm{L}^{*}, \mathrm{a}^{*}, \mathrm{~b}^{*}\right)$ and $\mathrm{pH}$ values of the breast meat of the quails $(\mathrm{P}>0.05)$. The current study is in accordance with the studies, in which aromatic plants and their essential oil derivatives were used, and had no effects on the color and $\mathrm{pH}$ values of the meat $(12,24,27,37)$.

There are also studies determining that pennyroyal and different aromatic plants had effects on the color and $\mathrm{pH}$ of the meat $(28,29)$. It was determined that Mentha 
piperita affected the $\mathrm{a}^{*}$ and $\mathrm{b}^{*}$ of the meat color intensities; however, it did not affect the $\mathrm{L}^{*}$ and $\mathrm{pH}$ in the quails (7). In their study on the effect of thyme and pennyroyal on the broiler meat color and $\mathrm{PH}$ value in the broilers, Pirmohamammadi et al. (36) found that the pennyroyal affected the $\mathrm{L}^{*}$ value; however, it did not have any effects on the $\mathrm{a}^{*}, \mathrm{~b}^{*}$ and $\mathrm{pH}$ values compared to the control group. They also stated that thyme and pennyroyal increased the $\mathrm{pH}$ when used combined $(\mathrm{P}<0.05)$.

As a result, it was concluded that the pennyroyal (Mentha pulegium L.) significantly affected the growth performance without changing the carcass, internal organs, or the meat quality (color, $\mathrm{pH}$ ) in the Japanese quails.

\section{Financial Support}

This research received no grant from any funding agency/sector.

\section{Ethical Statement}

This study was approved by the Kafkas University Animal Experiments Local Ethics Committee (KAÜHADYEK/2020-008).

\section{Conflict of Interest}

The authors declared that there is no conflict of interest.

\section{References}

1. Abd Al-Jaleel R (2012): Use of turmeric (Curcuma longa) on the performance and some physiological traits on the broiler diets. Iraqi J Vet Sci, 36, 51-57.

2. Abedini A, Hassanabadi A, Afzali N, et al (2017): The effect of different dietary levels of Pennyroyal (Mentha Pulegium L.), probiotic and antibiotic on performance, carcass characteristics and, sellected nutrients digestibility in broiler chickens. Arch Med Lab Sci, 3, 15-22.

3. Al-Ankari A, Zaki M, Al-Sultan S (2004): Use of habek mint (Mentha longifolia) in broiler chicken diets. Int J Poult Sci, 3, 629-634.

4. Al-Kassie GA (2010): The role of peppermint (Mentha piperita) on performance in broiler diets. Agric Biol J N Am, 1, 1009-1013.

5. Alizadeh Amoli Z, Mehdizadeh T, Tajik H, et al (2019): Shelf life extension of refrigerated, vacuum-packed rainbow trout dipped in an alginate coating containing an ethanolic extract and/or the essential oil of Mentha Aquatica. Chem Pap, 73, 2541-2550.

6. Aminzade B, Karami B, Lotfi E (2012): Growth response and carcass characteristics of Japanese quail to Mentha piperita plant supplementation. Anim Biol Anim Husb, 4, 24-27.

7. Aminzade B, Karami B, Lotfi E (2012): Meat quality characteristics in Japanese quails fed with Mentha piperita plant. Anim Biol Anim Husb, 4, 20-23.

8. Arjomandi M, Nobakht A, Pishchang J, et al (2011): Evaluoation the effects of using of probiotic, and pennyroyal (Mentha pulegium L.) medicinal plant on perormance of laying hens. J Appl Environ Biol Sci, 1, 164167.

9. Asadi N, Husseini SD, Tohidian M-T, et al (2017): Performance of broilers supplemented with peppermint (Mentha piperita L.) powder. Evid Based Compl Alt Med, 22, 703-706.

10. Aydin A and Bolukbasi SC (2020): Effect of supplementation of hen diet with pennyroyal extract (Mentha pulegium) on performance, egg quality and yolk TBARS values. Pak J Zoology, 52, 1045-1051.

11. Chalchat JC, Gorunovic MS, Maksimovic ZA, et al (2000): Essential oil of wild growing Mentha pulegium $L$. from Yugoslavia. J Essent Oil Res, 12, 598-600.

12. Cho JH, Kim HJ, Kim IH (2014): Effects of phytogenic feed additive on growth performance, digestibility, blood metabolites, intestinal microbiota, meat color and relative organ weight after oral challenge with Clostridium perfringens in broilers. Livest Sci, 160, 82-88.

13. Cross D, Acamovic T, Deans S, et al (2007): The effects of dietary inclusion of herbs and their volatile oils on performance, dietary digestibility and gut microflora in chickens from 7 to 28 days of age. Br Poultry Sci, 48, 496506.

14. Dale N (1994): National research council nutrient requirements of poultry-ninth revised edition. J Appl Poult Res, 3, 101-101.

15. Demir E, Kilinc K, Yildirim Y, et al (2008): Comparative effects of mint, sage, thyme and flavomycin in wheat-based broiler diets. Arch Zootech, 11, 54-63.

16. Erhan M, Aktaș Ș, Ürüșan H (2015): The effects of supplementation of pennyroyal (Mentha Pulegium L) on meat fatty acid composition and shelf-life in broilers. Ataturk Univ Vet Bilim Derg, 10, 179-185.

17. Erhan M, Bölükbaşı Ş, Ürüşan H (2012): Biological activities of pennyroyal (Mentha pulegium L.) in broilers. Livest Sci, 146, 189-192.

18. Erkan N, Doğruyol H, Günlü A, et al (2015): Use of natural preservatives in seafood: Plant extracts, edible film and coating. Food and Health, 1, 33-49.

19. Geran M, Irany M, Dehpourjoybari A (2010): The effect of pennyroyal essential oil on performance of broilers. 1-3. Proc 5th cong of new idea in agric.

20. Ghalamkari G, Toghyani M, Landy N, et al (2012): Investigation the effects using different levels of Mentha pulegium L.(pennyroyal) in comparison with an antibiotic growth promoter on performance, carcass traits and immune responses in broiler chickens. Asian Pac J Trop Biomed, 2, S1396-S1399.

21. Goodarzi M and Nanekarani S (2014): Effects of feeding Mentha pulegium L. as an alternative to antibiotics on performance of broilers. APCBEE Procedia, 8, 53-58.

22. Gümüş R, Erol HS, Imik H, et al (2017): The effects of the supplementation of lamb rations with oregano essential oil on the performance, some blood parameters and antioxidant metabolism in meat and liver tissues. Kafkas Univ Vet Fak Derg, 23, 395-401.

23. Gümüş R, Gelen SU, Ceylan ZG, et al (2017): Bıldırcın rasyonuna katılan kekik uçucu yă̆ının göğ̈̈s etinin bazı mikrobiyolojik ve fizikokimyasal özelliklerine etkisi. FÜ Sağ Bil Vet Derg, 31, 153-158. 
24. Hong JC, Steiner T, Aufy A, et al (2012): Effects of supplemental essential oil on growth performance, lipid metabolites and immunity, intestinal characteristics, microbiota and carcass traits in broilers. Livest Sci, 144, 253-262.

25. Horwitz W and Latimer GW (2005): AOAC Official methods of analysis of AOAC International. AOAC Official methods of analysis of AOAC International. AOAC International, Gaithersburg, MD, USA.

26. Kačániová M, Petrová J, Mellen M, et al (2019): Impact of anise (Pimpinella anisum) and mint (Mentha piperita) essential oils to microbial activity in chicken meat. J Microbiol Biotechnol Food Sci, 4, 28-31.

27. Kennedy O, Mbaba E, Iso I, et al (2020): Effects of turmeric rhizome powder on growth, carcass and meat quality of Japanese quails fed sorghum-soybean-based diets. Livest Sci, 11, 1-7.

28. Kirkpinar F, Ünlü HB, Serdaroğlu M, et al (2014): Effects of dietary oregano and garlic essential oils on carcass characteristics, meat composition, colour, $\mathrm{pH}$ and sensory quality of broiler meat. Br Poult Sci, 55, 157-166.

29. Küçükyilmaz K, Kiyma Z, Akdağ A, et al (2017): Effect of lavender (Lavandula Stoechas) essential oil on growth performance, carcass characteristics, meat quality and antioxidant status of broilers. S Afr J Anim Sci, 47, 178188.

30. Lee KW, Everts H, Kapperst HJ, et al (2003): Dietary carvacrol lowers body weight gain but improves feed conversion in female broiler chickens. J Appl Poult Res, 12, 394-399.

31. Mondal MA, Yeasmin T, Karim R, et al (2015): Effect of dietary supplementation of turmeric (Curcuma longa) powder on the growth performance and carcass traits of broiler chicks. SAARC J Agric, 13, 188-199.

32. Murbach Teles Andrade BF, Nunes Barbosa L, da Silva Probst I, et al (2014): Antimicrobial activity of essential oils. J Essent Oil Res, 26, 34-40.
33. Nobakht A, Norani J, Safamehr A (2011): The effects of different amounts of Mentha pulegium L.(pennyroyal) on performance, carcass traits, hematological and blood biochemical parameters of broilers. J Med Plant Res, 5, 3763-3768.

34. Ocak N, Erener G, Burak Ak F, et al (2008): Performance of broilers fed diets supplemented with dry peppermint (Mentha piperita L.) or thyme (Thymus vulgaris L.) leaves as growth promoter source. Czech J Anim Sci, 53, 169.

35. Ölmez M (2018): Etlik piliç karma yemlerine ilave edilen yarpuzun (Mentha pulegium L.) besi performans1, karkas kalitesi ve bazı kan parametreleri üzerine etkisi. Doktora. Atatürk Universitesi Sağlık Bilimleri Veteriner Hayvan Besleme ve Beslenme Hastalıkları, Erzurum.

36. Pirmohamammadi A, Daneshyar M, Farhoomand P, et al (2016): Effects of Thymus vulgaris and Mentha pulegium on colour, nutrients and peroxidation of meat in heatstressed broilers. S Afr J Anim Sci, 46, 278-284.

37. Ri CS, Jiang XR, Kim MH, et al (2017): Effects of dietary oregano powder supplementation on the growth performance, antioxidant status and meat quality of broiler chicks. Ital J Anim Sci, 16, 246-252.

38. Shafiei A, Salehinezhad F, Gholizadeh K, et al (2014): Effects of using different herbs mixture on fat percentage and other carcass traits of broilers of Chaharmahal and Bakhtiyari province. J Bio \& Env Sci, 4, 84-91.

39. Shamlo R, Nasr J, Kheiri F (2014): Effects of various levels of pennyroyal (Mentha pulegium L.) on carcass characteristics and serum cholesterol in broiler. Res Opin Anim Vet Sci, 4, 453-457.

40. Şahin T, Sural T, Ölmez M, et al (2020): Bitkisel ekstrakt karışımlarının broylerlerde performans, karkas randımanı ve bazı iç organ ă̆ırlıkları üzerine etkisi. Vet Hek Der Derg, 91, 137-146. 